\title{
Unreliability and Gender?
}

\author{
Untrusted Female Prophets in Ancient Greek \\ and Jewish Texts ${ }^{1}$
}

Hanna Tervanotko (University of Helsinki and Katholieke Universiteit
Leuven)

In this article I analyze disbelief of the divine messages transmitted by female figures in the Jewish texts Liber Antiquitatum Biblicarum, Jubilees, and the Sibylline Oracles. After a careful reading of these passages I turn to the portrayal of the figure of Cassandra in ancient Greek literature. While Cassandra's prophecies are truthful, she is not believed and instead is accused of being mentally ill. Significantly, Cassandra does not appear randomly in ancient Greek texts; her depiction invites the public to ask questions concerning truth and persuasion. This article considers the treatment of Cassandra as a possible model for understanding the characterizations of women prophets as unreliable in ancient Jewish texts. Finally I argue that whereas in Greek texts both men and women appear as unreliable prophets, in the Jewish texts unreliability appears to be a female characteristic.

"And the spirit of God came upon Miriam one night, and she saw a dream and told it to her parents in the morning, saying, 'I have seen this night...' And when Miriam told of her dream, her parents did not believe her." (L.A.B. 9:10)

\section{Introduction}

People throughout antiquity believed in the power and importance of individuals who delivered messages with divine origins. The above-quoted passage, in which Miriam's parents disbelieve her prophetic report, thus raises questions concerning the figure of Miriam and female prophets. The Hebrew Bible contains a few references to female prophets, and their portrayal does not give an unbiased image of women as prophets. Later Jewish texts, composed during the Hellenistic era, also witness women entering into communication with God. These texts also transmit a peculiar image of women who perform prophetic roles. On the one hand, women communicate with God, and thus they

1 Earlier versions of this paper were presented at the International Meeting of the Society of Biblical Literature in Vienna in July 2014 and at the OTSEM meeting in Hamburg in September 2014. I am grateful to the participants of both meetings for their feedback. I am particularly grateful to Prof. Reinhard Kratz, whose critical remarks pushed my own thinking. During my stay at Yale University in Spring 2015 I benefited from frequent conversations with Prof. John Collins and Prof. Emily Greenwood.

2 For translation, see D. J. Harrington, "Pseudo-Philo," in The Old Testament Pseudepigrapha (ed. J.H. Charlesworth; 2 vols.; New York: Doubleday, 1983-1985), 2.297-378, 315-16. 
appear as truthful prophets. On the other hand, when they transmit that communication to other people, they are not believed. Were women considered unreliable prophets?

In what follows I analyze disbelief in divine messages transmitted by women by focusing on three different texts of the late Second Temple era, all of which portray women in a prophetic role: Liber Antiquitatum Biblicarum, Jubilees, and the Sibylline Oracles. In these three texts, well-known female figures engage in prophetic activities, yet they are faced with resistance, and the messages they transmit are not believed to be authentically divine.

After a careful reading of these passages I then analyze why these women, who seemingly convey messages of divine origin, are portrayed as unreliable diviners. In order to shed more light on the purpose of such literature, I look at the portrayal of the figure of Cassandra that appears in ancient Greek texts as the disbelieved figure par excellence. While Cassandra's prophecies are truthful, she is not believed and is accused of being mentally unbalanced. Significantly, Cassandra does not appear randomly in ancient Greek texts. Rather this figure, who mostly appears as a protagonist of tragedies, serves a particular purpose. She invites the public to ask questions concerning truth and persuasion. As this aspect has not yet been taken into consideration regarding the Jewish texts, I ask to what extent the literary purposes assigned to Cassandra can also explain the unreliability that appears to characterize the Jewish female prophets.

In a comparison of the portrayals of Jewish and Greek female prophets, ${ }^{3} \mathrm{I}$ aim to shed new light on the depiction of female prophets in ancient Jewish texts and to add to our knowledge of cross-cultural influences in the ancient eastern Mediterranean. ${ }^{4}$ I argue that the use of Jewish female prophets is not coincidental. Rather, they appear to have a particular narratological function

3 "Jewish female prophet" should be understood here anachronistically. This term refers to the reception of female prophets in Jewish texts. I do not discuss the history of the various texts that refer to the female prophets or their historicity here.

4 See e.g., A. Lange, "Literary Prophecy and Oracle Collection: A Comparison Between Judah and Greece in Persian Times," in Prophets, Prophecy, and Prophetic Texts in Second Temple Judaism (eds. M. Floyd and R.D. Haak; London: T\&T Clark, 2006), 248-75; idem, "Oracle Collection and Canon: A Comparison Between Judah and Greece in Persian Times," in Jewish and Christian Scripture as Artifact and Canon (eds. C. A. Evans and H.D. Zacharias; London: T\&T Clark, 2009), 9-47; A. Hagedorn, "Looking at Foreigners in Biblical and Greek Prophecy," VT 57 (2007): 432-48; Y.S. Kupitz and K. Berthelot, "Deborah and the Delphic Pythia: A New Interpretation of Judges 4:4-5," in Images and Prophecy in the Ancient Eastern Mediterranean (eds. M. Nissinen and C. E. Carter; FRLANT 233; Göttingen: Vandenhoeck \& Ruprecht, 2009), 95-124; A.C. Hagedorn, "The Role of the Female Seer/Prophet in Ancient Greece," in Prophets Male and Female: Gender and Prophecy in the Hebrew Bible, the Eastern Mediterranean, and the Ancient Near East (eds. J. Stökl and C.L. Carvalho; Ancient Israel and Its Literature 15; Atlanta: Society of Biblical Literature, 2013), 101-25. See also the various publications by M. Nissinen, e.g., "Prophetic Madness: Prophecy and Ecstasy in the Ancient Near East and in Greece," in Raising Up a Faithful Exegete: Essays in Honor of Richard D. Nelson (eds. K. L. Noll and B. Schramm; Winona Lake, Ind.: Eisenbrauns, 2010), 3-29. 
in these texts and, significantly, the expressions of distrust and concerns about unreliability are a part of the narrative. It is the author's intention to present women as characters whose prophecies are not believed, even as the audience is aware of their truthfulness. Narratologically, it is not the female prophets who are unreliable - it is actually the narrators. ${ }^{5}$ In the end of the article, I tentatively discuss the cross-cultural influences and dependencies between the two corpora.

\section{Material and Methods}

Before moving on to my textual analysis, a few methodological principles, fundamental for the following investigation, need to be introduced. The first concerns the material under analysis. It is important to remember that the material that refers to Jewish and Greek female prophets is not evenhanded. Notably, concerning the Jewish texts, we do not have first-hand witnesses to the ancient female prophets, and our knowledge of what happened relies entirely on ancient authors' testimonies regarding them. In analyzing how the prophets were received, we need to look at the secondary sources that incorporate narratives of prophetic events. In contrast, some of the questions posed to the Delphic Pythia are preserved in historical or quasi-historical texts. ${ }^{6}$ In addition, the nature of the Jewish and Greek sources is different. The ancient Jewish texts have a primarily religious function, whereas the scope of those Greek texts that are taken into consideration in this study is broader. For instance, they contain epic poetry and tragedies. These texts, which were originally composed to be performed in front of live audiences in the contexts of festivals, had a different audience from that of the Jewish texts. Given the disparity between the materials under comparison, answers to comparative questions may not be readily available in the sources.

Second, the present study requires careful attention to terminology, because the texts under consideration are preserved in different languages. For instance, the texts employ different terms while discussing the individuals who deliver divine messages, the intuitive diviners. The Jewish texts composed

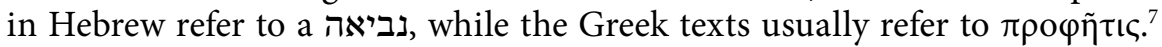
Another term frequently employed in the Greek texts in relation to intuitive diviners is $\mu \alpha \dot{v} \nu \tau \iota \varsigma$, often translated as "seer." Sometimes the nuances of these terms are not distinguishable in the ancient texts. ${ }^{8}$ The Delphic Pythia, for ex-

5 The term "unreliable narrator" was coined by W.C. Booth, The Rhetoric of Fiction (2d ed.; Chicago: The University of Chicago Press, 1983), 157-59.

6 For the list of questions, see J. Fontenrose, The Delphic Oracle, Its Responses and Operations, with a Catalogue of Responses (Berkeley and Los Angeles: University of California Press, 1978).

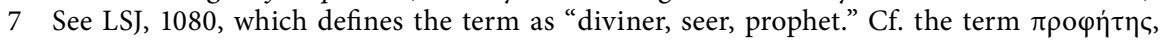
which is defined as one who speaks for a God and interprets his will to man.

8 Ibid. For a broader discussion see e.g., M. A. Flower, The Seer in Ancient Greece (Berkeley: University of California Press, 2008), 22-37, 84-91. 
ample, is called both mantis and prophetis. ${ }^{9}$ Semantic overlaps between these two terms are also reflected in recent scholarship. Most scholars are willing to accept that the "seers" performed tasks that were in many aspects similar to those of Jewish "prophets."

In light of these remarks it is clear that one cannot simply rely on terms that would refer to prophetic figures and assume their correlation with one another. Therefore, in order to compare the portrayal of the Greek and Jewish characters I will employ the often quoted definition of Manfred Weippert, who sees prophecy as a process of intermediation and defines it as a cognitive experience such as a vision or audition through which a person encounters a revelation and later transmits what was revealed to his or her audience. ${ }^{11}$ Thus, instead of fixing exact terminology for different religious specialists, I prefer analyzing phenomenology, i.e., what the action of prophecy entails.

\section{Distrust for Female Prophets in the Ancient Jewish Texts}

The question concerning disbelief in female prophets seems particularly relevant because in the Hebrew Bible only four women are portrayed as prophets: Miriam, Deborah, Huldah, and Noadiah. This leaves much space to speculate whether this means that female prophets simply did not exist, or whether they were received differently from male prophets.

Furthermore, it has often been pointed out that only small portions of their messages are preserved in the ancient texts. ${ }^{12}$ In fact, only Deborah

9 For the Pythia as a mantis, see Aeschylus, Eum. 29-33; as prophetis, see Plato, Ion 42, 321, 1322; Phaedr. 244b; Plutarch, Mor. 414b. See L. Maurizio, "Anthropology and Spirit Possession: A Reconsideration of the Pythia's Role at Delphi," The Journal of Hellenic Studies 115 (1995): 69-86, 70.

10 Greek seers apparently performed different types of activities to gain knowledge of the divine will. See e.g., Teireisias, who performs bird augury. Jewish texts, in contrast, seldom report on anything other than direct revelation, in which the word simply comes to a prophet. But note 1 Sam 9:9, which presents a prophet (נביא) as similar to a seer (הראה); it is possible that both terms applied to the same function. The term seer is not applied to female figures and will not be discussed in this study.

11 M. Weippert, "Prophetie im Alten Orient," Neues Bibel Lexikon 3 (2001): 196-200; A. Lange, "Greek Seers and Israelite-Jewish Prophets," VT 57 (2007): 461-82, 464. Weippert's definition has been used in the field of biblical studies in comparisons of Hebrew Bible prophecy and literary traditions witnessing to ancient Near Eastern and Mediterranean inquiries into divine will. See e.g., Lange, "Literary Prophecy and Oracle Collection"; idem, "Oracle Collection and Canon"; M. Nissinen, "What Is Prophecy? An Ancient Near Eastern Perspective," in Inspired Speech: Prophecy in the Ancient Near East: Essays in Honor of Herbert B. Huffmon (eds. J. Kaltner and L. Stulman; JSOTSup 372; London: T \& T Clark, 2004), 17-37.

12 Miriam's speeches are preserved in Exod 15:20-21 and Num 12:1-15; Micah 6:4 also refers to Miriam's prophetic function. For the figure of Deborah, see Judg 4:4-10, 14; 5:1-31. For Huldah, see 2 Kgs 22:14-20; 2 Chr 34:22-28. Apart from these figures, the Hebrew Bible preserves references to some unnamed female prophets, e. g., Isa 8:3. The most fundamental studies on these figures include R. Burns, Has the Lord Indeed Spoken only through Mo- 
and Huldah are treated as prophetic oracles. Some scholars have therefore suggested that the title "prophet" should be treated as an anachronism when it concerns women. ${ }^{13}$

Given the sparseness of references and prophetic content attributed to women in the Hebrew Bible, my analysis will turn to those women who somehow transmit divine messages in other ancient Jewish texts. I will study each case separately, highlighting how they receive such messages and how these messages are received by their audiences.

\subsection{Miriam in Liber Antiquitatum Biblicarum}

I will first discuss the figure of Miriam in Liber Antiquitatum Biblicarum (L.A.B.). ${ }^{14}$ L.A.B. is a Jewish composition that was probably originally composed in Hebrew but currently survives only in a Latin version. L.A.B. renarrates biblical history preserved from Genesis to 1 Samuel, which concerns the period from the creation of Adam to the death of Saul, generally following the sequence of the biblical narrative, but singling out some of the most prominent events and characters for the writer. ${ }^{15}$ Thus, L.A.B. provides an example of a renarrated Pentateuchal text.

An important feature of L.A.B. is its notable awareness of non-biblical traditions. Scholars have pointed out that the composition has many roots in the ancient Jewish traditions and legends on which various rabbinic texts are based, and which reveal a character that is somewhat close to aggadic midrashim. ${ }^{16}$ The author of L.A.B. seems to have been selective with the range

ses? A Study of the Biblical Portrait of Miriam (SBLDS 84; Atlanta: Scholars Press, 1987); U. Rapp, Mirjam: Eine feministisch-rhetorische Lektüre der Mirjamtexte in der hebräischen Bibel (BZAW 317; Berlin: de Gruyter, 2002); S. Ackerman, "Why Is Miriam also among the Prophets? (And is Zipporah among the Priests?)" JBL 121 (2002): 47-80; I. Fischer, Gotteskünderinnen: Zu einer geschlechterfairen Deutung des Phänomens der Prophetie und der Prophetinnen in der Hebräischen Bibel (Stuttgart: Kohlhammer, 2002); W. C. Gafney, Daughters of Miriam: Women Prophets in Ancient Israel (Minneapolis.: Fortress, 2008).

13 See e.g., Burns, Has the Lord Indeed Spoken only Through Moses, 79.

14 For my previous studies on this text, see e.g., H. Tervanotko, "Speaking in Dreams: The Figure of Miriam and Prophecy," in Prophets Male and Female, 147-68, 162-64.

15 The text is often quoted as "Pseudo-Philo." For the origin of the title, see G. Kisch, PseudoPhilo's Liber Antiquitatum Biblicarum (Publications in Medieval Studies 10; Notre Dame, Ind.: The University of Notre Dame, 1949), 3-5. Other fundamental studies on L.A.B. include, L. Cohn, "An Apocryphal Work Ascribed to Philo of Alexandria," JQR 10 (orig. series, 1898): 277-332; C. Perrot and P.-M. Bogaert, in collaboration with D. J. Harrington, Les Antiquités Bibliques: Introduction Littéraire, Commentaire et Index (2 vols.; Sources Chrétiennes 230; Paris: CERF, 1976); F. J. Murphy, Pseudo-Philo: Rewriting the Bible (New York: Oxford University Press, 1993); H. Jacobson, A Commentary on Pseudo-Philo's Liber Antiquitatum Biblicarum with Latin Text and English Translation 1-2 (UGJU 31; Leiden: Brill, 1996); B. N. Fisk, Do You Not Remember? Scripture, Story and Exegesis in the Rewritten Bible of Pseudo-Philo (JSPSup 37; Sheffield: Sheffield Academic Press, 2001).

16 Cohn, "An Apocryphal Work Ascribed to Philo of Alexandria," 314, 322. 
of narratives that are incorporated in the new composition. The vast majority of scholars currently agree that the text was written in the first century C.E. ${ }^{17}$

The author of L.A.B. narrates events that precede Moses' birth, and in L. A. B. 9:9-10 the author turns to the figure of Miriam, to whom Moses' birth is announced. ${ }^{18}$

And Amram from the tribe of Levi went out and took a wife from his own tribe. When he had taken her, others followed him and took their own wives. And this man had one son and one daughter; their names were Aaron and Miriam. And the spirit of God came upon Miriam one night, and she saw a dream and told it to her parents in the morning, saying, "I have seen this night, and behold a man in a linen garment stood and said to me, 'Go and say to your parents, Behold he who will be born from you will be cast forth into the water; likewise through him the water will be dried up. And I will work signs through him and save my people, and he will exercise leadership always." And when Miriam told of her dream, her parents did not believe her. ${ }^{19}$

In this passage the figure of Miriam remarkably features as a character to whom divine plans are communicated via dreams. Ancient Jewish texts often do not distinguish between a dream and a vision; here L.A.B. 9:10 employs terminology that points to a nocturnal dream. The spirit of God comes to Miriam during the night, and later when she reports her dream (Lat. somnium), she refers to "this night." The dream appears to take place somewhat involuntarily; Miriam does not appear to invoke it. Further, the passage explains that it was God's messenger who appeared in the dream. The text refers to "a man (Lat. vir) in white linen." Scholars have argued that such a description closely resembles language employed for angels in ancient Jewish texts. ${ }^{20}$

17 The discussion concerning the first century date is framed by the question of whether the composition was written prior to or after the destruction of the Temple. The text contains only one reference to the Temple (L.A.B. 19:7), which is not explicit and may therefore be uncertain. If the absence of the Temple is a sign that the writer is not interested in this topic (or that it no longer exists), as some scholars think, it may follow that the text was written after the destruction of the Temple. See e.g., James, The Biblical Antiquities of Philo, 29-32; Perrot and Bogaert, Pseudo-Philon Les Antiquités Bibliques 2.67-70; Harrington, "PseudoPhilo," 2.299; Murphy, Pseudo-Philo, 262-68; Fisk, Do You Not Remember, 330. For proposals regarding a later date, see Jacobson, Liber Antiquitatum Biblicarum, 1.209, who thinks the most plausible date is sometime in the second century C.E. Similarly, M.T. DesCamp, Metaphor and Ideology: Liber Antiquitatum Biblicarum and Literary Methods through a Cognitive Lens (Biblical Interpretation Series 97; Leiden: Brill, 2007), 3-4. An even later date is proposed by Cohn, "An Apocryphal Work Ascribed to Philo of Alexandria", 328; A. Zeron, "Erwägungen zu Pseudo-Philo's Quellen und Zeit," JSJ 11 (1980): 38-52; T. Ilan, "The Torah of the Jews of Ancient Rome," JSQ 16 (2009): 363-95, 381.

18 Cohn, "The Apocryphal Work of Philo of Alexandria," 318, notes that the mention of Miriam's prophecies concerning her younger brother appears in various midrashim: e.g. b. Sotah 12 b; Exod. Rab. 2.4.

19 For translation, see Harrington, "Pseudo-Philo," 2.315-16.

20 Perrot and Bogaert, Les Antiquités Bibliques 2.59-63; Murphy, Pseudo-Philo, 59; Jacobson, Liber Antiquitatum Biblicarum, 1.419-21. Cf. the descriptions of angels especially in Ezek 9:11; Dan 10:4, where the figures are dressed in linen garments. 
The contents of Miriam's dream make reference to future events. The messenger declares: "likewise through him (Moses) the water will be dried up." This is clearly an allusion to the events of the crossing of the Sea of Reeds (Exod 14-15). ${ }^{21}$ Moreover, the dream refers to miracles that Moses will perform and his leadership over the people. These future events are communicated to Miriam as revelation coming from God, and it is this revelatory event that qualifies her as a prophetic figure in L.A.B. Importantly, Miriam is the member of Moses' family to whom his significance is revealed.

Next, in L. A. B. 9:10, Miriam in her turn communicates the contents of her dream to her parents. Yet when she tells them about her experience, her parents do not believe her dream account. At this point the passage is particularly short and does not contain details on what causes their disbelief. Nothing is said concerning the relationship between Miriam and her parents. Thus, it is difficult to draw conclusions about how they received her.

This passage has been treated by Frances Flannery-Dailey, who analyzes dreams attributed to women in the broader context of Hellenistic-Jewish dreaming traditions. She points out that while men's dreams are generally received without hesitation or resistance, some kind of polemical response appears to be a standard with women's dreams. Flannery-Dailey suggests that this resistance reflects the perception that it would be ridiculous for a woman to receive a divinely-sent dream. ${ }^{22}$ Regarding Miriam in L.A.B. 9:9-10 she argues that the author's point is to demonstrate Miriam's inferiority vis-à-vis Moses, who in the biblical passages is treated as the true prophet who could speak with God face to face (Deut 34:10; Num 12:6-8). This observation suggests that the author had some sort of gender bias while composing this text..$^{23}$ As Jacobson points out, there are many different versions of the literary tradition about a dream or prophecy regarding Moses' future, but this seems to be the only one to reflect disbelief in the dream..$^{24}$ Such treatment seems hardly coincidental.

While I appreciate Flannery-Dailey's overall analysis of the passage and her remarks on the author's biased treatment of Miriam, her argument concerning Miriam's inferiority is not entirely convincing. Most notably, elsewhere in L.A. B. the author positions Miriam on the same level with Moses and Aaron. In particular, L.A.B. 20:8 stipulates that Miriam was one of the early Israelite leaders who performed alongside Moses and Aaron. ${ }^{25}$ Given this egalitar-

21 Fisk, Do You Not Remember, 31. Fisk's ideas here are influenced by E. Reinmuth, PseudoPhilo und Lukas: Studien zum Liber Antiquitatum Biblicarum und seiner Bedeutung für die Interpretation des lukanischen Doppelwerks (WUNT 74; Tübingen: Mohr Siebeck, 1994), 111, who calls such a narrative feature "Korrelationsprinzip." See also L.A. B. 9:14, which likewise echoes the sea events.

22 F. Flannery-Dailey, Dreamers, Scribes, and Priests: Jewish Dreams in the Hellenistic and Roman Eras (JSJSup 60; Leiden: Brill, 2004), 120.

23 Flannery-Dailey, Dreamers, Scribes, and Priests, 121.

24 Jacobson, Liber Antiquitatum Biblicarum, 1.421.

25 "And after that Moses was dead, the manna ceased to come down for the children of Israel, and then began they to eat the fruits of the land. And these are the three things which God 
ian presentation of the three figures, I am inclined to think that the disbelief does not appear to concern Miriam directly. In light of the positive portrayal of Miriam elsewhere in L.A.B. it is indeed difficult to think that the author wanted to present Miriam in a discredited light. Moreover, I do not think the author aimed at ridiculing Miriam. Instead another explanation should be sought for the choice to disbelieve her message.

In contrast with the narrative strain in which the surrounding characters do not believe Miriam, the internal plot of the narrative seems to serve a different purpose. It demonstrates that Miriam was right and that Miriam should thus be seen as a true prophetic figure. The distrust in Miriam's message thus appears to contribute to the creation of an unreliable narrator. One reason for the use of distrust as a narratological device could be that the author wanted to create suspense. The parents do not know the significance of their offspring. Moreover, such uncertainty could explain Miriam's active role in Exod 2, where she follows the basket in order to see what will happen to Moses. She had a suspicion of what might happen and she wanted to confirm it. ${ }^{26}$ I will return to these observations in further discussion below.

\subsection{Rebecca in Jubilees}

The second century B. C. E. Jubilees elaborates on the role of the figure of Rebecca vis-à-vis the Pentateuchal narrative. In Jubilees, Rebecca significantly becomes a character to whom future events are announced through dreams. As the information she receives later proves to be true, it is difficult to imagine that her dreams would have anything but a divine origin in the author's mind.

The first instance in which Rebecca's role as a dreamer of divine dreams is recognizable is in the passage that concerns Jacob's departure. In Genesis (Gen 27:42) Rebecca is vaguely told that Esau plans to kill Jacob: "But the words of her elder son Esau were told (ויגדה) to Rebecca." Thus, the Genesis context leaves open how Rebecca actually gets to know Esau's intention to kill Jacob. Meanwhile, the Jubilees narrative offers a specific explanation.

27:1 Rebecca was told in a dream what her older son Esau had said. So she sent and summoned her younger son Jacob and said to him: 27:2 "Your brother Esau will now try to get revenge against you by killing you. 27:3 Now, my son, listen to me. Set out and run away to my brother Laban - to Haran. Stay with him for a few days until your brother's anger turns away and he stops being angry at you and forgets everything that you have done to him. Then I will send and take you back from there." 27:4 Jacob said:

gave his people for the sake of three persons, that is, the well of the water of Mara for Maria's sake, and the pillar of cloud for Aaron's sake, and the manna for the sake of Moses. And when these three came to an end, those three gifts were taken away from them." (L.A.B. 20:8). See Harrington, “Pseudo-Philo," 2.329.

26 For the early interpretations of the Exodus 2, see the article of Agnethe Siquans in this issue. 
"I am not afraid. If he wishes to kill me, I will kill him." 27:5 She said to him: "May I not lose my two sons in one day." 27:6 Jacob said to his mother Rebecca: "You are indeed aware that my father has grown old, and I notice that he has difficulty seeing. If I left him, it would be a bad thing in his view because I would be leaving him and going away from you. My father would be angry and curse me. I will not go. If he sends me, only then will I go." 27:7 Rebecca said to Jacob: "I will go in and tell him. Then he will send you." (Jub. 27:1-7) 27

Betsy Halpern-Amaru, who has pioneered the analysis of the female figures in Jubilees, has pointed out that this version of the Gen 27:42-46 account addresses a number of problems in the earlier account. First, the author explains that Rebecca learned about Esau's plans through a dream. Second, Jacob's refusal to go without his father's permission explains why Rebecca, immediately after the conversation with Jacob, goes to Isaac. ${ }^{28}$ As Jacob refuses to leave unless his father sends him away, Rebecca needs to convince Isaac to do that.

The passage refers to Rebecca's dream in one single verse. It simply states that Rebecca was informed about Esau's plans in a dream without explaining whether the dream contained any divine figures or, moreover, how Esau's plans were communicated. One thing is certain, nevertheless: Rebecca is so convinced about her dream that she advises her son to leave, and she refers to her dream in her discussion with Jacob. When she talks with Jacob, her son does not reject the content of the dream. Rather, he states that he is not afraid of his brother, and he refuses to follow Rebecca's advice unless it is his father who sends him. Jacob's reaction implies that he on some level may believe the content of the dream and realizes he is in danger, but that he is not willing to follow his mother's instruction.

Another passage in Jubilees, 35:6-9, adds to Rebecca's role as a visionary, in the context of the treatment of her death. In this passage Rebecca dreams of her death, and after that she knows she will die soon. When she tells this dream to her son Jacob, he does not believe her; rather, he points out her strengths.

35:6 She said to him: "My son, throughout my entire lifetime I have noticed no improper act in you but only proper one(s). However, I will tell you the truth, my son: I will die during this year and will not make it alive through this year because I have seen the day of my death in a dream - that I will not live more than 155 years. Now I have completed my entire lifetime that I am to live." 35:7 Jacob laughed at what his mother was saying because his mother said to him that she would die, but she was sitting in front of him in possession of her strength. She had lost none of her strength because she could come and go; she could see and her teeth were strong. No sickness had touched her throughout her entire lifetime. 35:8 Jacob said to her: "Mother, I would be fortunate if my lifetime approached your lifetime and (if) my strength would remain

27 Translations from Jubilees follow J.C. VanderKam, The Book of Jubilees (C.S.C. O. 511; Scriptores Aethiopici 88; Leuven: Peeters, 1989), unless otherwise indicated.

28 B. Halpern-Amaru, The Empowerment of Women in the Book of Jubilees (JSJSup 60; Leiden: Brill, 1999), 89. 
with me in the way your strength has. You are not going to die but rather have spoken idle nonsense with me about your death." 29

This passage resembles the one discussed above, in the sense that Rebecca receives information concerning the future through a dream. In this case it concerns herself. In this context, the author articulates Jacob's disbelief, which differs remarkably from the previous passage where Jacob did not object the dream. In Jub. 27:1-7, Jacob points out that Rebecca appears to be in good health, and there is no reason to think that she would die anytime soon. Jacob thus appeals to rational arguments and his own sensory observations before concluding that the content of Rebecca's dream is nonsense.

Despite Jacob's response and disbelief, the audience of Jubilees knows that Rebecca dies later in the Genesis narrative. The text also confirms the dream later, when Jub. 35:27 narrates Rebecca's death: "She and her sons ate and drank that night. She died that night at the age of three jubilees, one week, and one year [= 155 years]. Her two sons Esau and Jacob buried her in the twofold cave near their father's mother Sarah." Therefore, it appears that similar to the case of Miriam's dream in L.A.B., the audience has known all along that Rebecca is telling the truth. The message that she has received in her dream is a true prediction of future events, which she attempts to transmit to her closest kin, her son Jacob. Unlike the audience of the passage, Jacob does not see the value of Rebecca's dream.

In my view, these two accounts of Rebecca's dreams express the idea that she serves as a transmitter of divine will in Jubilees. The passages contain only a few details about the dreams. Yet the fact that the dreams are later fulfilled confirms their divine origin. Halpern-Amaru has argued that in these situations where Rebecca acts on divine assistance, the particular scope that she has in her mind is to secure the future of her family. While she seemingly acts as a loving mother, and her maternal concerns are emphasized throughout the passage, she also has other motivations. She guides her husband to make decisions that will benefit the entire family. ${ }^{30}$

A question arises, whether the author of Jubilees composed these passages only to settle exegetical inconsistencies in the Pentateuch narrative. The situation is peculiar because, on the one hand, these passages draw attention to Rebecca receiving divine knowledge through dreams. On the other hand, in neither of the two passages does Rebecca simply deliver her message and have it received as a divinely inspired note. In the first one Jacob does not really care for it but wants to challenge Esau. In the second passage he, even more so, openly disbelieves her and tells her she is wrong. This makes the audience wonder, what might be the purpose of such a dubious portrayal?

\footnotetext{
29 Note that in this passage the Ge'ez reading and the Hebrew manuscripts from Qumran differ slightly. See Halpern-Amaru, Empowerment of Women, 136.

30 Halpern-Amaru, Empowerment of Women, 89-90.
} 
As noted above, Halpern-Amaru concentrates on the exegetical problems that Jubilees tries to solve vis-à-vis the Pentateuchal narrative, and she explains these passages accordingly. Flannery-Dailey, in addition, suggests that dreams that prepare people for their deaths are frequent in the ancient Near East, Greece, and Rome, and that they help characters to prepare their families for their death. ${ }^{31}$ In the context of the second dream, with Rebecca's warning of Jacob, her behavior seems to correspond to such a purpose. Yet, Flannery-Dailey also finds gender bias in the narratives concerning Rebecca's dreams. She postulates that the passage of $J u b$. 27:1 is a prime example of how the dreams of women serve men. Rebecca's dream concerns the need to take care of Jacob's fate, while her own story is not narrated. ${ }^{32}$ Flannery-Dailey also takes into account the disbelief element with regard to women's dreams. She argues that Jacob's laugh is a sign of disbelief and thus, even if the dream narrative's portrayal of Rebecca is in a positive light, i.e., that she is concerned about the future of her family, ultimately the dream cannot be construed as positive. ${ }^{33}$

Before agreeing or disagreeing with her interpretation, I would like to look at the portrayal of Rebecca in Jubilees in a more comprehensive way. HalpernAmaru makes the important observation that Rebecca is a prominent figure in the text of Jubilees. She argues that in the author's mind Rebecca is a stronger character than her husband Isaac. ${ }^{34}$ This claim finds support in various passages where Rebecca indeed plays a more central role than her husband. Just to give a few examples: Abraham teaches Rebecca in Jub. 19:15-31, and this depiction suggests that Abraham saw Rebecca as his successor instead of Isaac. Moreover, when Jacob realizes that Abraham has died, he does not go to search for his father Isaac, but rather his mother Rebecca. Finally, in her death scene in $J u b .35$, Rebecca spends her last night with her two sons, who also bury her. Meanwhile, Isaac is not mentioned anywhere in this passage. ${ }^{35}$

I think that these passages offer sufficient evidence of the author's interpretation of Rebecca. It is clear that the author held Rebecca in very high esteem, and in that respect I find it difficult to agree with Flannery-Dailey's argument concerning ridicule or negative interpretations of Rebecca. In contrast, I

31 Flannery-Dailey, Dreamers, Scribes, and Priests, 231.

32 Flannery-Dailey, Dreamers, Scribes, and Priests, 137. Flannery-Dailey further proposes that dreams in which the dreamer foresees death should be interpreted in terms of the wider framework of familial care; see ibid., 231. Their function is to benefit other family members. Cf. Methusaleh's dream in 2 En. 70.

33 Flannery-Dailey, Dreamers, Scribes, and Priests, 120. Moreover, Flannery-Dailey maintains that since most other dreams in Hellenistic Judaism function to increase the status of the dreamer, this treatment of women's dreams reflects a certain bias. This question is part of a broader discussion that should also take into account the treatment of men's dreams.

34 Halpern-Amaru, Empowerment of Women, 37-42, argues that the treatment of Rebecca in Jubilees differs from that of the other matriarchs. Jubilees highlights the figure of Rebecca throughout its narrative.

35 Halpern-Amaru, Empowerment of Women, 64. It seems to have been the duty of the sons to bury their father. Yet, in the case of Sarah's death, Jubilees reports that Abraham buried her (Jub. 19:3). Hence, Isaac's absence is not easily justified. 
would suggest that Rebecca's function as a persona in the text is similar to that of Miriam. Both the author and the audience are aware of earlier narrative accounts of these events in other texts. They know that Rebecca did not have such visions or dreams in the Pentateuchal narrative. They also know how the story will end and that Rebecca is a trustworthy transmitter of the divine will. If the author did not actually aim at putting Rebecca in a negative light in this passage, the significance of presenting her as an unreliable prophet must be found elsewhere.

\subsection{Sibyl}

My next example of a Jewish female prophet is the figure of the Sibyl whose oracles are preserved in book 3 of the Sibylline Oracles. ${ }^{36}$ The Sibyl was a female prophet of pagan origin, who became known mostly in ancient Greek literature. ${ }^{37}$ She was associated with different oracular shrines that appear in the literature of the ancient eastern Mediterranean. In these texts the Sibyl was thought of as being possessed by Apollo, who delivered divine messages to her, which she in turn passed on to her audience.

The messages attributed to the Sibyl of book three of the Sibylline Oracles appear to have been composed by a Jewish author. ${ }^{38}$ In light of the established reputation of this figure, it is no wonder that Jews too were familiar with her. In contrast to the Sibyl of pagan origin, however, the figure adapted to the Jewish literature appears as "prophetess of the high God" (Sib. Or. 3.818), and her speeches incorporate biblical references. These connect her even more profoundly with Jewish tradition. The goal of the utterances attributed to the third Sibyl is to convince readers that the Jewish people play an important role in the history of the world, understood in broad terms to include the ancient eastern and Greek tradition. A second, perhaps even more important goal, was to prove that the Hellenistic world was ultimately subject to the Jewish God.

The treatment of the Sibyl's prophecy in the Sibylline Oracles differs remarkably from the treatments in other texts that bear witness to Jewish female prophets. Most notably, the Sibylline Oracles is a collection of oracles, similar to those attributed to prominent male prophets. In them, the Sibyl's prophesying is described in terms similar to those used for the male prophets who prophesy out of external need or because the word of God simply comes

36 For my understanding of the term "Jewish female prophet," see n. 3.

37 The ancient world knew of several Sibyls, who were associated with different oracle sites. The earliest references to the figure appear in Heraclitus, fr. 75 (=Plutarch, Mor. 397A). Plato cites the Sibyl in Phaedr. 244b.

38 For the Jewish origin, see e.g., J.J. Collins, The Sibylline Oracles of Egyptian Judaism (SBLDS 13; Missoula, Mon.: SBL, 1974), 1-18; idem, "The Jewish Transformation of Sibylline Oracles," in Seers, Sibyls, and Sages in Hellenistic-Roman Judaism (JSJSup 54; Leiden: Brill, 1997), 181-97; R. Buitenwerf, Book III of the Sibylline Oracles and its Social Setting (SVTP 17; Leiden: Brill, 2003). 
to them (see e.g., Isa 1:1; Mic 1:1). The Sibyl, too, utters divine messages out of an external need and because she cannot help it. ${ }^{39}$ Thus, "An oracle of the great God rose in my breast, and he ordered me to prophesy about the entire earth" (Sib. Or. 3.162-163). And again, "But why did God also inspire me to say what kind of misery will come upon all people first, what subsequently, and what finally? And why did he inspire me to say what the beginning of these things will be?" (Sib. Or. 3.196-198). "When my mind stopped uttering the divine oracle, and I begged the great Begetter to stop the pressure, again an oracle of the great God rose in my breast, and he ordered me to prophesy about the entire earth, and to reveal the future to kings" (Sib. Or. 3.295-299). ${ }^{40}$

These examples suggest that the Sibyl's receipt of divine messages is described in physical terms. It appears to be a bodily experience. In the written Sibyl traditions, the figure appears as a wild ecstatic, who is in an almost unconscious state during her performance. ${ }^{41}$ Such a description differs radically from the usual picture of prophets in Jewish texts, where the authors were particularly interested in explaining that their prophets were completely understandable. They did not act in ecstasy, but only through a divine commission. ${ }^{42}$ However, even given the general tendency to depict the prophets as rational figures, the Hebrew Bible itself contains some references to prophecy that is almost a painful experience, e.g., Isa 21:3-4; Jer 4:19; Hab 3:16. It seems that from the Hellenistic era on, ecstasy was not so foreign for the Jewish prophets, and elements of ecstatic prophecy were transmitted into Jewish ideas of prophecy. Philo, for example, appears to appreciate such prophecy and 4 Ezra 6:35-37 portrays prophecy as a restless act. ${ }^{43}$

Book 3 of the Sibylline Oracles contains only marginal notes on the figure of Sibyl herself. She is, however, given the title "prophet," unlike the figures of Miriam and Rebecca, who appear to perform only in ad hoc prophetic roles. In a Greek context the use of such a title implies that the Sibyl was understood as someone connected to a particular shrine and someone who was an established prophet. ${ }^{44}$

39 J. Lightfoot, The Sibylline Oracles (Oxford: Oxford University Press, 2007), 10.

40 See also lines 589-591. Translations follow Buitenwerf, Book III of the Sibylline Oracles.

41 Plutarch, Mor. 397b, refers to Sibyl (through Heraclitus): "But Sibylla with raving mouth uttering things without laughter and without charm of sight or scent, reaches a thousand years by her voice on account of the god." Similarly Aristophanes, who ca. fifth century B. C.E. refers to Sibyl explicitly in Pax, 1096 and 1116, and more broadly in Av. 959-990 and Eq. 997-1096.

42 Lightfoot, The Sibylline Oracles, 18-23. Note that no ecstatic elements appear in the depictions of Miriam and Rebecca analyzed above. They appear as completely rational figures throughout the narratives.

43 Lightfoot, The Sibylline Oracles, 18. See, e.g., Quis Heres 249, 258, which describe Abraham as ecstatic; Spec. Leg. 1.65 speaks of prophets as possessed figures; Mos. 1.283 attests to the seer that addresses King Balak as a possessed character.

44 Lightfoot, The Sibylline Oracles, 21. This title is also used for Pythia, and it correlates with the LXX terminology, in which true prophets appear as prophetis and false ones as mantis. See e. g., L.H. Feldman, "Prophets and Prophecy in Josephus," JTS 41 (1990): 386-422. 
Yet the most explicit reference to the identity and origin of the character appears at the end of the third book of the Sibylline Oracles. It contains the alleged autobiography of Sibyl, which reveals the author's view of her identity. She has Jewish origins and comes from Babylon, but is sent to Greece to prophesy among the Greeks. Prophesying events that are still in her future but that are in the past for the audience reading the text is a narrative trick to claim credibility ${ }^{45}$ However, a short passage of the third book suggests that Sibyl's prophecies too might have met with resistance. In Sib. Or. 3.814b-816a Sibyl laments people's disbelief towards her: "Some will say that I am Sibylla, born of Circe as mother, and Gnostos as father, a crazy liar."

According to Greek mythology Circe is the daughter of Heluios and Perse. In Odyssey 10.133-269 she is portrayed as a wicked goddess who transformed Odysseus and his friends into pigs. ${ }^{46}$ Further, in Greco-Roman mythology Circe is associated with luxuriousness and levity. Thus, the allegation that Sib$\mathrm{yl}$ is offspring of a greedy goddess intends to disqualify Sibyl as a prophet. ${ }^{47} \mathrm{An}$ accusation that Sibyl was an illegitimate daughter of Circe meant that she had pagan origins. Moreover, a character from such a family background could never be a respectable prophet of the true God. She can only be mistrusted, and consequently she is called a liar. ${ }^{48}$ Meanwhile, there is no certainty concerning the figure of Sibyl's father, Gnostos, who appears nowhere outside of this passage.

Sibyl talks to a fictitious Greek audience, which is presented as not believing her. She comforts herself with the thought that her prophecies are true and reliable: eventually everything she foretells will come true, and people will remember her, not as a cheat, but as a prophet of the great God (cf. lines 3.568572)..$^{49}$ She claims to be the daughter-in-law of Noah (Sib. Or. 3.823-826). ${ }^{50}$ Moreover, in light of her correct ex eventu prophecies, the audience of this text is expected to receive her as a true prophet.

Recent scholarship has paid attention to the audience for this text. Book 3 frequently addresses the Greeks, but this may be part of the composition's internal plot, and the text could also be written for a Jewish audience. ${ }^{51}$ Both were familiar with the figure of Sibyl. The author's purpose may have been

45 Sibyl for instance predicts the Exodus events in Sib. Or. 3.248-264 and foresees Homer in 3.419-432.

46 See Od. 10.316-317.

47 Buitenwerf, Book III of the Sibylline Oracles, 298. See e. g., Mem. 1.3.6-7; Adul. amic. 52e.

48 Buitenwerf, Book III of the Sibylline Oracles, 299.

49 Ibid.

50 "For when the world was inundated with waters, and a certain man, a single famous person, survived by sailing upon the waters in a wooden house, together with beasts and birds, so that the world would be filled again... His relative am I, and I am of his blood. He went through the first things. All the things (which would happen) later were revealed. So, let all these things uttered from my mouth be taken as coming true." Sib. Or. 3.823-829.

51 Collins, The Sibylline Oracles of Egyptian Judaism, 54; Buitenwerf, Book III of the Sibylline Oracles, 389. 
to "develop the common ground shared by Egyptian Jews and their environment. In this way a framework is established within which the Greeks might learn to appreciate Judaism in terms of their own values and ideals, but also the Jews might learn to appreciate what they held in common with the Greeks." ${ }^{2}$

Buitenwerf discusses the particular purposes of this text to the Jews. There is obvious rhetorical force in having a pagan prophet reveal to the Greeks that the Jews are the epitome of religiosity and morality. At minimum, the author thereby encourages the Jewish audience members to continue practicing piety and righteousness. ${ }^{53}$ Moreover, Buitenwerf argues that divine riddles and descriptions of divine reward and punishment serve as authorial devices to keep the listeners' attention fixed on the message of the text. Buitenwerf accepts, too, that the author's imitation of Homeric style in particular could have had an entertainment function. ${ }^{54}$ Therefore, the text could have simultaneously served different purposes.

\subsection{Preliminary Conclusions}

In this section of the study I have aimed at identifying those female figures who receive divine messages, and who in their turn transmit them further, in the texts of the late Second Temple era. Similar to the female prophets of the earlier texts, and the references in the Hebrew Bible in particular, the number of female visionaries remains low. Altogether the texts attest to three female figures who can be recognized as experiencing some type of communication with God.

The key elements of their prophetic acts were described above. In particular, new accounts of divine messages attributed to female figures ground themselves in established figures, who are known to their audiences and whose messages do not, in fact, reveal anything "new." The accounts of Miriam and Rebecca reflect familiar elements. They have dreams concerning the continuity of their families, and they share them with family members, who then reject their messages. The figure of Sibyl, in contrast, prophesies for a broader audience (her own family is located in ancient mythology, so they are out of the picture entirely), but they too reject her prophetic message.

Thus, interestingly, all of these female visionaries are rejected in some way by their audiences. Such treatment at the level of the plot raises questions about whether this treatment is a systematic narratological device. In what follows, I will turn to some ancient Greek portrayals of the Trojan princess Cassandra, as a prophetic figure. Their treatment of Cassandra will shed new light on the question of disbelief as a narratological device and its purposes.

52 Collins, The Sibylline Oracles of Egyptian Judaism, 54.

53 Buitenwerf, Book III of the Sibylline Oracles, 389.

54 Ibid., 389-90. 


\section{Disbelief in Greek Female Prophets: Cassandra}

When one turns to look at female prophets and disbelief in the context of ancient Greek literature, the figure of Cassandra is an obvious starting point. Cassandra has been analyzed in multiple studies, many of which aim for a comprehensive image of her treatment in Greek literature. ${ }^{55}$ The present discussion will focus on the element of disbelief in her prophecies.

The earliest references to Cassandra are preserved in Homer's epics, which refer to her as one of the daughters of King Priam and Queen Hecuba. ${ }^{56}$ These texts that concentrate on Cassandra's family relations and beauty do not preserve any explicit references to her prophetic role. ${ }^{57}$ Later Greek texts bring forth her other qualities, in particular her divinatory skills. The first text referring to Cassandra as a mantis is Pindar's Pythian Odes 11.31-35:

Atreus' heroic son himself died when at last he came to famous Amyklai, and he brought death on the prophetic [ $\mu \alpha \dot{v \tau \tau} v]$ maiden, after he despoiled of their luxury homes of the Trojans, who were visited by fire for the sake of Helen. ${ }^{58}$

55 The most comprehensive studies include J. Davreux, La légende de la prophétesse Cassandre d'après les textes et les monuments (Liège: Faculté de philosophie et letters, 1942); D. Neblung, Dis Gestalt der Kassandra in der antiken Literatur (Betäge zur Altertumskunde 97; Stuttgarg/Leipzig: Tebner, 1997); S. Mazzoldi, Cassandra, la vergina e l'indovina: Identità di un personaggio da Omero all'Ellenismo (Filologia e critica 88; Pisa: Istituti editoriali e poligrafici internazionali, 2001). See further Hagedorn, "Role of the Female Seer/Prophet in Ancient Greece," 101-126.

56 "Then Idomeneus, though his hair was flecked with gray, called to the Damaans, and learing among the Trojans roused them to flight. For he slew Othryoneus, a guest at Troy from Cabesus, who had only recently come following the report of war; and he asked in marriage the fairest of the daughters of Priam, Cassandra; he brought no bride price, but promised a mighty deed, that by force he would drive the sons of Achaeans out of the land of Troy. To him the old man Priam promised he would give her, and bowed his head to it, and Othryoneus fought trusting in his promises" (Il. 13.363-369); "Nor did any one else learn of them, whether man or fair-belted woman; but Cassandra, peer of golden Aphrodite, having gone up on Pergamus, caught sight of her dear father as he stood in the chariot, and the herald, the city's crier; and him she saw who lay on the bier in the wagon drawn by the mules. She uttered a shrill cry then, and shouted throughout all the town: 'Come, men and women of Troy, and look on Hector, if ever while he still lived you rejoiced at his coming back from battle; since great joy was he to the city and to all the people"' (Il. 24.697-705). C. W. Macleod, ed., Homer: Iliad Book XXIV (Cambridge Greek and Latin Classics; Cambridge: Cambridge University Press, 1982), 146, emphasizes that if Homer was aware of more stories of Cassandra, he did not leave any trace of them in the Iliad. Cf. N. Richardson, The Iliad: The Commentary (Cambridge: Cambridge University Press, 1993), 6:348, who thinks that it is impossible to know whether Homer had in mind Cassandra's prophetic gifts, or whether her role as an announcer of bad news influenced her later interpretation. Richardson claims that the poet knew more traditions than those he tells the readers. Note that all translations in this section follow LCL.

57 Cf. Il. 24.697-705, where Cassandra appears to have knowledge that is not available to everyone. This passage has sometimes been interpreted as the first witness to Cassandra's prophetic skills. For discussion, see Mazzoldi, Cassandra, la vergina e l'indovina, 115-17.

58 For the use of the term mantis vs. prophet, see section 2 of this study. 
This short reference makes it clear that from early on Cassandra was connected with prophetic skills. The passage does not preserve any details about how Cassandra's prophecies were received. Consideration of later references to Cassandra provide further information.

The prophetic role attributed to Cassandra is more distinguished in the Greek tragedies of the Persian era. They narrate the origin of Cassandra's prophetic skill. According to Aeschylus' Agamemnon, Apollo fell in love with Cassandra and granted her the gift of prophecy. Cassandra appears to have received the prophetic gift (Ag. 1202-1214) in the moment she promised to become Apollo's lover. When she later broke her promise, she incurred his wrath. ${ }^{59}$ Apollo permitted her to keep the gift of prophecy, but he turned the gift into a curse: no one would ever believe her predictions:

Cassandra: The seer Apollo assigned me to this function.

Chorus: "You don't mean that he was struck with desire, god though he was?

Cassandra: Till now I was ashamed to say this.

Chorus: Yes, prosperity makes anyone more coy.

Cassandra: But he was a wrestler, really breathing delight upon me.

Chorus: Did you come together in the act of procreation?

Cassandra: I consented, and then I cheated Loxias.

Chorus: When you were already possessed by your inspired abilities?

Cassandra: I was already prophesying to my fellow-citizens about all they were to suffer.

Chorus: How then did you remain uncharmed by the wrath of Loxias?

Cassandra: After I had done him this wrong, I could never make anyone believe anything I said. ${ }^{60}$

While the passage does not explicitly describe this lack of credibility as a punishment, it can be understood as such. Scholars have underscored the uniqueness of a tale of a woman who would refuse a god in ancient Greek literature. The notion that a woman might refuse a god, even at a high cost, is a strange one. ${ }^{61}$

Cassandra's prophecies concern, most notoriously, the destruction of Troy, which she foresees. She warns the citizens about the Trojan horse, saying that

59 The same tradition is also found in Apollodorus, Ap.E. 3.7.5: "Wishing to gain Cassandra's favours, Apollo promised to teach her the art of prophecy; she learned the art but refused her favours; hence Apollo deprived her prophecy of power to persuade." For an alternative version concerning Cassandra's prophetic skills, see Anticlides of Athens (FGH 140, fr. 17). This version also attributes the prophetic skill to Apollo, the god of prophecy. According to this version Cassandra went to the temple of Apollo together with her brother Helenus, and little snakes licked her ears. This allowed Cassandra and her brother to hear the future.

60 Aeschylus, Ag. 1202-1212 (Sommerstein, LCL). By saying that she could never convince anyone to believe her, Cassandra almost implies that the choir she is conversing with should not believe what she is now saying. This is an excellent example of riddling speech. I thank Emily Greenwood for pointing this out to me.

61 E.g., T. Gantz, Early Greek Myth: A Guide to Literary and Artistic Sources (Baltimore: The Johns Hopkins University Press, 1993), 92. 
if the horse is brought into the city, the Greeks will destroy the Trojans. No one believes her, and the horse is admitted into the city, with the obvious disastrous results. Cassandra is unable to do anything to prevent the tragedies she predicts:

And at break of day, when the Trojans beheld the camp of the Greeks deserted and believed that they had fled, they with great joy dragged the horse, and stationed it beside the palace of Priam deliberated what they should do. As Cassandra said that there was an armed force in it, and she was further confirmed by Laocoon, the seer, some were for burning it, and others for throwing it down a precipice; but as most were in favor of sparing it as a votive offering sacred to a divinity, they betook them to sacrifice and feasting. (Ap.E. 5.16-19). ${ }^{62}$

When Troy falls to the Greeks, Cassandra is brought to Agamemnon as a concubine. He takes her with him when he returns home to Argos. These events are described, for instance, in Euripides' Trojan Women, where Cassandra predicts that it is because of her that Agamemnon will meet his doom (Tro. 353-360, 404-405). Upon her arrival in Argos, Cassandra continues to prophecy, predicting Agamemnon's death (e.g., Ag. 1246) and her own (e.g., Ag. 1256-1264).

Various passages that attest to Cassandra's prophecies contribute to her overall image as a prophet. Her prophecies concern future events, and she is able to predict what will happen. Her predictions do not appear to be responses to inquiries or consultations, but rather occur as spontaneous, involuntary revelations provided by her unfortunate gift. Some texts do not specify how Cassandra accesses divine knowledge (e.g., Epitome, see above). In other texts, however, Cassandra appears to experience visions that predict the future, which she, in turn, interprets. In Ag. 1114-1118, for example, she speaks explicitly of "seeing" when she cries out a warning of the approaching murder of Agamemnon:

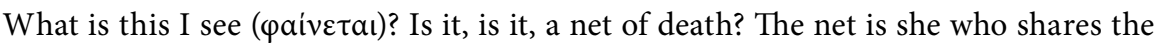
net, who shares the guilt of the murder! Let the insatiable spirit of strife raise a cry of triumph over the family for this sacrifice that merits stoning!

Recent studies have concluded that Cassandra appears to experience an ecstatic state in which she remains conscious of herself and her context. ${ }^{63}$ For instance, she is able to maintain a conversation with the chorus in Agamemnon (see above, Ag. 1202-1214). In this context she almost manages to convince the chorus of what is to come. The chorus of Agamemnon sympathizes with

62 One of the earliest witnesses to this tradition is the Tabula Iliaca Capitolina, where events of the Trojan fall are depicted. In one of the pictures Ajax drags Cassandra by the hair on the steps of the temple. See A. Sadurska, Les tables iliaques (Warsaw: Państwowe Wydawn, 1964).

63 Mazzoldi, Cassandra, la vergina e l'indovina, 100-102; Lightfoot, The Sibylline Oracles, 10, highlights the compulsion to speak that is characteristic of both Sibyl and Cassandra. At times their prophesying seems to take place against their will. 
her and listens to her. In Ag. 1249 the chorus cries: "No, if it is to be; but God forbid!" implying at least partial belief in Cassandra's prediction, combined with the hope that it will not be fulfilled. The chorus later asks who is the man who will commit the crimes $(A g .1251)$ and compares Cassandra's utterances to those of the Pythia, which are also difficult to understand (Ag. 1255) ${ }^{64} \mathrm{In}$ another text, Tro. 500, Hecuba recognizes and appears to acknowledge that Cassandra's utterances have divine origin: "My daughter Cassandra, you that

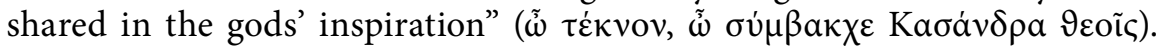
This portrayal strengthens the image that Cassandra is not, in fact, a madwoman. Nonetheless, she lacks the capacity to convince her audiences about her messages.

Again, as in the case of the Jewish female prophets, everything that Cassandra predicts in the ancient Greek literature actually happens. Therefore, while the characters around Cassandra do not believe her prophecies and accuse her of being mad, she herself appears as a truthful prophet. She presents herself in this guise (Ag. $1241 \dot{\alpha} \lambda \eta \vartheta$ ó $\mu \alpha v \tau \iota v)$, and not as a diviner who seeks to deceive. The audience of these texts, who would have been familiar with the existing traditions of ancient Greek tragedy, would have responded to these prophecies in ways that differ from the responses of the other characters in the play. For the audience, who knew the story of the fall of Troy as a fundamental myth, Cassandra would be recognizable as a true prophet, even when the other characters in the drama did not realize it. ${ }^{65}$

All in all, Cassandra is recognized as a truthful prophet, but her prophecy misses one fundamental quality: that of persuasion (peitho). Apollodorus' Epitome (3.7.5) explains this: "Apollo deprived her prophecy of power to persuade $(\pi \varepsilon i \vartheta \omega)$." Cassandra herself refers to this in $A g .1212$, where she explains that she cannot convince anyone. ${ }^{66}$ It is precisely this lack of persuasion that makes Cassandra a tragic figure in the Greek tragedies. Without persuasion, her audience cannot believe her. The discussion that follows will analyze this element of persuasion and its function in the Greek literature more in detail, to ask whether it also plays a role in the portrayals of the Jewish female prophets.

64 Similarly Mazzoldi, Cassandra, la vergina e l'indovina, 200-201 n. 324, who thinks that at times the chorus believes what Cassandra has to say.

65 K.H. Lee, Euripides, The Trojan Women (Glasgow: Macmillan Education, 1976), 142, writes: "Naturally enough, the chorus does not agree with Cassandra's conclusion. Their remarks, which are prompted by common sense and a reasonable appraisal of the situation, are in sharp contrast to the prophetic insight of Cassandra. Eventually they will learn, as we the audience know, that Cassandra's visions were $\sigma \alpha \varphi \tilde{\eta}$ after all. But this realization will come only after the tragedies of Greece and Troy have been worked out, at a time beyond the limits of this play." For a complex study on tragedies and the traditions they rewrite, see e. g., J.-P. Vernant and P. Vidal-Naquet, Myth and Tragedy in Ancient Greece (New York: Urzone, 1988)

66 For the irony that this passage preserves, see n. 60 . 


\section{Peitho and Culture of Persuasion}

After concluding that it is the lack of peitho, persuasion, that prevents Cassandra from convincing her audience, we should take a closer look at how this concept functions in ancient Greek texts. In several early Greek compositions, Peitho is a mythical all-powerful deity, usually portrayed as a female figure. In the Greek pantheon, Peitho stands for the power of speech over others. Mythically, she represents the charm of the voice, the seduction of speech, and the magic of words. ${ }^{67}$ Seldom rejected, she appears to exercise a power over other characters, who could not resist her. ${ }^{68}$

This is not the only function of peitho, though. Scholars have identified a transition from myth to reason, which seems to coincide with a secularization in the political and legal thought of the seventh and sixth centuries B.C.E. ${ }^{69}$ Such a shift determined the emergence of an autonomous world of speech and thought about language as an instrument. ${ }^{70}$ From this point on, dialogue-speech was what mattered. It was through speech that people participated in assemblies, established their command, and dominated others. Thoughts about language began to be elaborated along two major lines: as an instrument of social relations and as a means of knowing reality. Rhetoric and sophistry explored the former path, forging techniques of persuasion and developing the grammatical stylistic analysis of this instrument.

As a consequence of this transition, the dialogue triumphed as a literary form, and older forms of speech were devalued. Thus, Aristophanes writes:

I'm told they have both Arguments there, the Better, whatever that may be, and the Worse. And one of these arguments, the Worse, I'm told, can plead the unjust side of a case and win. So, if you learn this Unjust Argument for me, then I wouldn't have to pay anyone even a penny of these debts that I now owe on your account. (Lys. 112-118)

Plato similarly discusses the power of persuasion in his Phaedrus. He has Socrates argue that:

He who is to be a competent rhetorician need have nothing at all to, do, they say, with truth in considering things which are just or good, or men who are so, whether by nature or by education. For in the courts, they say, nobody cares for truth about these matters, but for that which is convincing; and that is probability, so that he who is to be an artist in speech must fix his attention upon probability. (Phaedr. 272c-d).

67 M. Detienne, The Masters of Truth in Archaic Greece (New York: Urzone, 1996). See e.g., Od. 1.337; Mor. 759b.

68 E.g., Aeschylus, Prom. 172, witnesses Peitho casting "honeyed words." Like the Sirens, Peitho is described in ways that are fundamentally ambivalent, both beneficent and harmful (see Od. 12.39-46, 184-193).

69 Detienne, The Masters of Truth, 104.

70 Ibid. 
The power of persuasion, which earlier texts had represented as Peitho personified, is now converted into autonomous speech. Peitho is closely connected with rhetoric, and the aim of rhetoric is persuasion (peitho). ${ }^{71}$

It should come as no surprise that elements of persuasion appear also in the Greek tragedies. ${ }^{72}$ Sometimes they contain technical terminology that the audience would be familiar with from other contexts and which they would relate to debates. ${ }^{73}$ At other times Greek tragedies portray speakers who aim at persuading any other person who shares the stage with them. ${ }^{74}$ The Cassandra of Agamemnon is a prime example of the need for general credibility. Cassandra demonstrates the importance of rhetoric for the function of prophetic speech. Despite her truthfulness (Ag. 1241 ả $\lambda$ Yó $\mu \alpha v \tau ı v)$ Apollo has deprived her of her persuasive powers, and her speech has no power over others. This defect is so serious that even if the speech is efficacious, Cassandra seems capable of producing only "vain" or even untrustworthy words. Without peitho, even a truthful prophet could not convince an audience, no matter the origin of the message. Incapable of persuasive speech, Cassandra's truthfulness is, so to speak, condemned to "nonreality" and her status as a truthful prophet is fundamentally undermined. ${ }^{75}$

\section{Context: Disbelief and Gender?}

The question still remains: is disbelief a general reaction to prophecies, or is it related in some specific way to gender? A potential answer to this question may lie in the reactions of people in Jewish and Greek texts to other prophets' messages. ${ }^{76}$

Out of the four named female prophets that appear in the Hebrew Bible, it is evident that Huldah (2 Kgs 22:3-20; 2 Chr 34:22-28) and Deborah (Judg 4:1-5:31) are portrayed as credible figures. People who consult them take heed of their advice. ${ }^{77}$

The responses to Jewish male prophets, in contrast, varies. The prophets of the Hebrew Bible are not automatically believed, and many of them meet difficulties while delivering their messages. Hosea's enemies cry that he is a fool (Hos 9:7), and Isaiah (Isa 28:7-9) and Micah (Mic 2:6) also meet resistance.

71 Detienne, The Masters of Truth, 104.

72 V. Bers, "Tragedy and Rhetoric," in Persuasion: Greek Rhetoric in Action (ed. I. Worthington; London: Routledge, 1994), 176-95.

73 Bers, "Tragedy and Rhetoric,"179-82. Note that Aeschylus' Ag. refers to "proofs" (352) and "evidence" (1366), terms that the audience may relate with a legal setting.

74 Bers, "Tragedy and Rhetoric,"183-84.

75 A. Dale, Euripides: Alcestis (Oxford, 1954), 328-68; Detienne, The Masters of Truth, 77.

76 For gender and prophetic agency in greater detail, see M. Nissinen, "Gender and Prophetic Agency in the Ancient Near East and in Greece," in Prophets Male and Female, 27-58.

77 These characters have been analyzed at length in other contexts. See n. 12 and the contribution of Jonathan Stökl in this issue. 
Perhaps the most complex image of a disbelieved prophet is that of Jeremiah. His audience does not listen to him, and in several passages he cries out about the misfortune of being obliged to prophesy against his will (e.g., Jer 11:18; $15: 10 ; 20: 7-18)$.

While these earlier compositions seem to reflect similar treatment of both male and female prophets without any gender bias, the situation is different in later texts. As demonstrated above, the female prophets in the Jewish texts of the late Second Temple era meet almost systematic resistance. In contrast, male characters such as Abraham, Levi, Amram and Enoch are associated with new prophetic traditions, such as appearing as dreamers in the texts. Flannery-Dailey argues that dreams in the Hellenistic era often functioned to increase the status of the dreamer. ${ }^{78}$ This claim seems to fit with the male characters in the preserved texts, which do not hint that their dreams or visions would be disbelieved. Thus, if this observation is correct, it seems that Jewish male and female prophets were not interpreted in evenhanded ways in the late Second Temple era. Women's prophetic messages were openly questioned, whereas the messages delivered by male prophets were not.

The Greek texts, in contrast, do not appear to reflect a similar bias. Disbelief is not a particularly characteristic response to female prophets in these texts. The Pythia, in fact, is the most well-known prophet of the ancient Greek texts. She performs as the mouthpiece of Apollo at the temple in Delphi. In Pindar's words (Pyth. 3.29) Pythia "has the mind that knows all things." She is variably called mantis (Aeschylus, Eum. 29, 33), prophetis (e.g., Plato, Ion. 42, 321, 1322; Phaedr. 244b; Mor. 414b) and promantis (Herodotus, Hist. 6.66, 7.111 and 141). ${ }^{79}$ The texts do not preserve references to disbelief in her messages. In contrast, her coherence and accuracy in the ancient texts have been outlined in recent studies. ${ }^{80}$ In some instances, she does not respond (e.g., Apollodorus, Ap.B. 2.6.2), and on those occasions Apollo himself comes to speak, but such failure does not seem to affect her credibility in any way. Nor does her credibility seem to be decreased in light of at least two passages of Herodotus' Histories that attest to Pythia's bribing $(5.63,6.66) .{ }^{81}$ Rather, these passages appear to confirm that she was treated as a credible figure in spite of her occasional flaws.

78 Flannery-Dailey, Dreamers, Scribes and Priests, 120-21, 247.

79 Maurizio, "Anthropology and Spirit Possession: A Reconsideration of the Pythia's Role at Delphi," 69-86.

80 Maurizio, "Anthropology and Spirit Possession: A Reconsideration of the Pythia's Role at Delphi," 79.

81 Maurizio, "Anthropology and Spirit Possession: A Reconsideration of the Pythia's Role at Delphi," 84. For the significance of the oracle of Delphi until the first centuries C. E., see H. Bowden, "Seeking Certainty and Claiming Authority: The Consultation of Greek Oracles from the Classical to the Roman Imperial Periods," in Divination in the Ancient Worlds: Religious Options and the Individual (ed. V. Rosenberger; Potsdamer Altertumswissenschaftliche Beiträge 46; Stuttgart: Franz Steiner Verlag, 2013), 41-60. 
Greek myths also bear witness to female prophets. Manto, the daughter of Teiresias (Diodorus Siculus 4.66.4-6, 9.33.2; Apollodorus, Ap.B. 3.7.7, Ap.E. 6.2-4), was the the mother of Mopsus, another seer. ${ }^{82}$ Mantinean Diotima, who appears in Plato's Symposium (201d), bears a name that suggests a connection between prophecy and the divine. According to Flower, she "represents a type of individual who was recognizable to Plato's contemporaries." ${ }^{3}$ Remarkably, she appears to have taught Socrates the nature of love (Symp. 202-203); the same passage also refers to Diotima's plausible mantic skills. Socrates tells his companion Agathon that by encouraging the Athenians to offer sacrifices, Diotima was able to postpone the plague by ten years. ${ }^{84}$

In the context of these examples, it appears that the treatment of Cassandra as an unreliable female prophet is not representative of a general Greek view of female prophets and prophecy. Prophetic messages by female figures might indeed be received as plausible, just as male prophets - such as Laocoön in Apollodorus' Bibliotheca (Ap.E. 5.16-17) and Teiresias in Sophocles' Oedipus tyrannus-might encounter disbelief. In this latter text, Oedipus attacks Teiresias personally (387-389), calling him a "wizard hatcher of plots, this crafty beggar, who has sight only when it comes to profit, but in his art is blind." Oedipus thus asks (390) "Why, come, tell me, how can you be a true prophet?" 85

These examples - of female prophets who are believed, as well as of male prophets who are not - it seems that disbelief is not a characteristic response toward either male or female prophets in the ancient Greek texts. These texts do not demonstrate any noticeable gender bias. Rather, disbelief seems to be used in Greek texts in service of particular narrative purposes, as the example of Cassandra demonstrates.

\section{Conclusions}

In this article I have analyzed responses of disbelief toward female prophets in Jewish and Greek texts. In my opinion these examples of disbelief serve integral purposes in each textual corpus. As with Cassandra, the Jewish prophetic figures of the late Second Temple era should be understood as true prophets. The audience knows they are reliable, but the narrators present them as characters who have failed to persuade their audiences. But despite their momentary failures as prophets, these female figures (Miriam, Rebecca, the Sibyl) do not lose their prestige. This is because the audiences of the texts are aware of

82 Flower, The Seer, 211.

83 Flower, The Seer, 212.

84 "And now I shall let you alone, and proceed with the discourse upon Love which I heard one day from a Mantinean woman named Diotima: in this subject she was skilled, and in many others too; for once, by bidding the Athenians offer sacrifices ten years before the plague, she procured them so much delay in the advent of the sickness."

85 For discussion, see Flower, The Seer, 133-36. 
their truthfulness, despite the narrators who point out that they were not believed. The implications in the two distinct corpora are, thus, somewhat similar, and the similarities are strongest in the figure of the Sibyl, known from the ancient Greek texts and influenced by the Greek literature.

Differences too are identifiable: the Jewish and Greek texts differ from each other in their treatment of gender in relation to prophetic roles. In the Greek context distrust is not related to gender; both male and female prophets risk being disbelieved. Therefore, when the author of a text has the narrator present a trustworthy prophet as unreliable, this should be viewed as a narratological device.

In contrast, the Jewish texts of the late Second Temple era demonstrate a gender bias in their treatment of distrust, which appears to occur only in connection with female prophets. While visions and prophetic messages attributed to male figures served to increase their status, female prophets do not seem to benefit in the same way. What, then, was the purpose of having a narrator emphasize that prophetic women - whose prophecies the audience knows to be legitimate - were in fact unreliable authorities? It may be that authors wanted to underscore the idea that female prophets were only believed after their statements were proven to be prophetic, and not automatically. This, in turn, would render them second-tier spokespeople vis-à-vis their male counterparts.

The conclusion that the Jewish and the Greek texts of the Hellenistic era present female prophets differently has some important consequences. In light of this analysis it seems evident that the negative, dubious image of female prophets in the Jewish texts was not inherited from the Greek texts. Instead, motives for the bias against the female prophets must be sought elsewhere. 